17. Lodatko, E., Kondrashova, L. (2015). Teacher of elementary school in the socio-cultural dimension of society. Kiev: Word.. 232 p.

18. Rudenko, NM (2016). Preparation of future teachers of elementary school in college conditions for the use of interactive technologies in mathematics classes (Ph.D Dissertation in Pedagogical Sciences). Kyiv. 288 p.

19. Churkina, N.I. (2010). Pedagogical education as a sociocultural phenomenon: structure, functions, mission in society. Bulletin of the Tomsk State University. 341. 103-107.

20. Bader, V.I. (2019). Modernization of primary education: STEM-approach in the formation of communicative competence of younger students. Primary education: problems and solutions: Materials of the II International Scientific and Practical Conference of Namangan State University. Namangan: Namangan State University. 32-42.

21. Voloshina, O.V. (2007). The socio-cultural component of the education of future primary school teachers in the Great Britain (Ph.D Dissertation). Thesis. Kyiv. 24 p.

22. Kalita, N. (2015). Preparation of elementary school teacher in the context of modern educational paradigms. Topical issues of humanities sciences. Interuniversity collection of scientific works of young scientists of the Ivan Franko Drohobych State Pedagogical University. 14. 265-269.

\title{
LODATKO Evgen,
}

Professor, Doctor in Pedagogy, Professor of High School Pedagogy and Educational Management Department, Bohdan Khmelnytsky National University at Cherkasy

\section{MATHEMATICAL COMPETENCE OF THE FUTURE TEACHER OF PRIMARY SCHOOL: SOCIO-CULTURAL ASPECTS}

Abstract. Introduction. The article analyzes the sociocultural dimensions of mathematical competence as well as methodological and mathematical activity of primary school teachers based on current normative documents and trends in the system of teacher training for native primary education.

Purpose. The study is targeted at revealing those aspects of professional mathematical and methodologicalmathematical training, which are stipulated by professional potentials of the graduate departments of the specialty "Primary Education", including mathematical development of instructors majoring in teaching mathematics and methods of teaching mathematics.

Methods. The article employs analysis of the main premises of normative documents and generalization of the experience of mathematical and methodologicalmathematical preparation of teacher-trainees of primary school, as well as socio-cultural tendencies that imply shifting an emphasis from the sphere of knowledge to the public sphere.

Results. The main constituents of the system of training teacher-trainees of primary school to mathematical and methodological-mathematical activity are classified as standardized and non-standardized, the content of which is autonomously determined by the departments and mainly by specialists who are not in any way related to mathematical education or even elementary mathematical activity. This state of affairs does not correspond to the current STEM-tendencies in school education and natural-mathematical and cognitive-linguistic achievements of elementary and primary school students, which are reflected in the studies of TIMSS and PIRLS.

The originality of the problem at issue is that it proposes the ordering of standardized and non-standardized constituents in the system of preparation of primary school teacher-trainees. It determines the stages of their mathematical and methodological-mathematical professional development, which require didactically motivated content, cognitive and activity support in accordance with the current educational paradigm and value reference points of contemporary elementary education.

Conclusion. To sum up, the article substantiates the necessity to focus attention on purpose-setting, value orientations, socio-cultural norms and strategies of achieving educational and upbringing objectives so that educational results were sought after by society at the time when they are being reached. The complexity of this problem necessitates fostering a substantially standardized core of teacher training of elementary school that will set the ground for their mathematical and methodologicalmathematical professional activity.

Keywords: Future Teacher; Primary School; Mathematical Competence; Socio-Cultural Aspects.

Одержано редакиією 18.01.2019 Прийнято до публікаиії 29.01.2019

DOI 10.31651/2524-2660-2019-1-96-103

ORCID 0000-0003-4304-4962

\section{ЖОРОВА Ірина Ярославівна,}

доктор педагогічних наук, доцент, перший проректор,

професор кафедри педагогіки й менеджменту освіти,

КВНЗ «Херсонська академія неперервної освіти" Херсонської обласної ради e-mail: zhorova.ks@gmail.com

УДК 378.046-021.68-051:502(09)

\section{СУЧАСНI ТЕХНОАОГIÏ РОЗВИТКУ ПРОФЕСІОНАМІЗМУ ПЕДАГОГІВ У СИСТЕМІ ПІСАЯДИПАОМНОЇ ОСВІТИ УКРАЇНИ}

У статті розкрито зміст поняття "професіоналізм педагога", представлено узагальнені результати досліджень учених шодо визначення структури професіоналізму педагога та фаз його розвитку. Розглянуто сучасні технології розвитку профресіоналізму педагогів у наиіональній системі післядипломної освіти.

Ключові слова: професіоналізм педагога; освітні технологї̈; післядипломна освіта.
Постановка пробцеми. Національна система освіти на початку третього тисячоліття характеризується зміною освітньої парадигми, онов енням змісту та технологій навчання. Досягнення позитивних результатів гуманізації змісту освіти, реалізація мюдиноцентрованої спрямованості навчання i виховання $\epsilon$ 
можливими завдяки передусім професійно-творчій діяльності вчителя.

Сьогодні, як і раніше, пріоритетом державної освітньої політики є забезпечення якісної підготовки педагогічних кадрів, здатних до творчої праці та професійного розвитку через створення цілісної системи неперервної освіти. Важливою манкою неперервної освіти $\epsilon$ система післядипломної освіти педагогічних кадрів, у середовищі якої відбувається розвиток професіоналізму педагогів, його духовної культури та інноваційного творчого стилю мислення.

Інноваційний характер післядипломного освітнього простору детермінований зростанням інформаційних потоків, упровадженням нових педагогічних технологій, необхідністю задоволення потреб особистого й професійного розвитку педагогів, які подекуди не повною мірою готові до впровадження нововведень у шкільну практику, що зумовАює певні утруднення в професійній діяльності, серед яких:

- організація проектної й дослідницької діяльності учнів;

- розробка й реалізація методичних модемей, технологій і прийомів;

- аналіз результатів освітнього процесу i ix подальше використання в процесі проектування педагогічної діяльності;

- вивчення, узагальнення й творче використання передового педагогічного досвіду та ін.

Указані причини актуалізують пошук сучасних прийомів, методів, технологій розвитку професійної компетентності педагогів у закладах післядипломної освіти.

Аналіз останніх досліджень i публікацій. Дослідження становлення й розвитку професіоналізму педагога знайшли своє відображення в науковому доробку І.Д. Багаєвої, Н.В. Гузій, Г.С. Даниловой, $\quad$ С.А. Дружилова, Н.В. Кузьміної, В.В. Панчука, В.О. Сластьоніна й інших учених.

Проблеми освіти дорослих висвітлені в роботах А.І. Анциферової, С.Г. Вершмовського, С.І. Зміїва, А.І. Кузьмінського, Ю.М. Кулюткина, В.В. Олійника, П.В. Худоминського та ін.

Утім і сьогодні питанням, що потребує системного вивчення $є$ підготовка вчителів до виконання завдань Нової української школи, формування в них готовності до реалізації академічної сво- боди, мотивації до самоосвіти та самовдосконалення в системі післядипломної освіти як середовищі розвитку професіоналізму педагогів.

Мета статті - розкрити зміст поняття "професіоналізм педагога" та розглянути сучасні технології розвитку професіоналізму педагогів у національній системі післядипломної освіти.

\section{Виклад основного матеріалу.}

Перші спроби наукового обгрунтування феномену "професіоналізм педагога" знаходимо в дослідженнях Н.В. Кузьміної, яка визначає його, як уміння педагога формувати в учнів готовність до розв'язання завдань за час, відведений на вивчення певного предмету $[1$, с. 11$]$.

Студіювання професіоналізму педагога з позиції акмеологічного підходу, проведене В.О. Сластьоніним, засвідчимо, що "професіоналізм учителя - якісна характеристика його як суб'єкта педагогічної діяльності, що відображає високий рівень професійної компетентності й особистісної готовності до продуктивного вирішення педагогічних завдань. Як інтегральне особистісне утворення, професіоналізм учителя поєднує у своїй структурі мотиваційно-ціннісний, когнітивний та операціонально-діяльнісний компоненти" [2, с. 6].

Конвергенція поглядів учених щодо розуміння професіоналізму як вершини

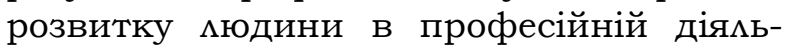
ності свідчить, що сама по собі "вершинна модель" передбачає можливості спаду, регресії після певних досягнень. Сучасні акмеологічні теорії професійного розвитку базуються на моделі "багатовершинного" феномену, згідно 3 якою акме означає не кінцевий шлях життєвого руxy i розвитку, а ту вершину, 3 якої відкриваються нові горизонти подальшого поступу. Таким чином, сучасна наука орієнтується на "багатовершинну" й "інтенціально-динамічну" моделі акме мюдини. Значимість цих модемей визначається можливостями виокремлення різних акмеологічних періодів на тих чи інших стадіях життєдіяльності [2, с. 14].

Аналізуючи зміст і сутність поняття "професіоналізм", І.Д. Багаєва визначає, що професіоналізм педагогічної діяльності характеризується особистісною й діяльнісною сутністю. Особистісну сутність професіоналізму складають професійні знання та специфічне ставмення педагога до діяльності. Діяльнісну 
сутність складає комплекс умінь (гностичних, самовдосконалення, спілкування, уміння планувати й організовувати власну діяльність і діяльність учнів) [3, с. 14].

Викликає інтерес також запропонована науковцем І.Д. Багаєвою модемь професіоналізму педагогічної діяльності, до складу якої входять такі елементи: професіоналізм знань (теоретична база професіоналізму), професіоналізм педагогічного спілкування (уміння використовувати систему знань у практичній діяльності), професіоналізм самовдосконалення (готовність до саморозвитку) [3, c. 15].

У науковому доробку Н.В. Гузій професіоналізм представцено як інтегративне особистісно-діяльнісне новоутворення вчителя-вихователя. Вона враховує методомогічний принцип єдності особистості й діяльності, розглядає професіоналізм педагогічної діяльності й професіоналізм особистості в нероздільній цілісності та виокремлює їхні смислоутворюючі чинники: педагогічну майстерність і творчість [4, с. 159].

Рівні розвитку професіоналізму вчителів через оцінку продуктивності педагогічної діяльності визначає Н.В. Кузьміна: мінімальний - репродуктивний (передача наявного обсягу знань); низький - адаптивний (iнформування 3 урахуванням особливостей аудиторії); ередній модемюючий (реалізація стратегії навчання 3 окремих тем курсу); високий системно-модемюючий (реалізація стратегії навчання з предмету в цілому); найвищий - системно-модемюючий діяльність та поведінку (формування особистості учня в процесі навчання) [1].

Цікавими $є$ положення щодо розуміння структури професіонахізму педагога, висунуті С.А. Дружимовим. У своїх роботах професіоналізм він розглядає 3 позицій системного підходу як динамічний стан мюдини. Дослідження, проведені науковцем, показали, що відбувається зміна структури професіоналізму, яка стосується як складу системоутворюючих елементів професіоналізму, так і зв'язків між ними. Виходячи 3 цього положення, він визначає фази, які характеризують зміну структури професіоналізму: екстенсивного розвитку (накопичення знань, формування вмінь i навичок), інтенсивного розвитку (аналіз та відбір елементів, які $є$ необхідними дия забезпечення успішної діяльності), стагнації (накопиченням деструктивних елементів, які $€$ наслідком негативного індивідуального та узагальненого досвіду), деградації (зменшення елементів, що утворюють структуру професіоналізму та розривом зв'язків між ними) [5].

Аналіз наукових досліджень свідчить, що професіоналізм учителів $€$ інтегративною якістю особистості, що характеризується морально-духовними якостями, акмеологічною позицією, педагогічною технікою, професійною компетентністю, які екстеріоризуються у творчій педагогічній діяльності та забезпечують формування в учнів киючових і міжпредметних компетентностей.

Розвиток професіоналізму педагогів відбувається в системі неперервної освіти. Основним ціннісним виміром якості сучасної післядипломної освіти $€$ професійний розвиток педагога 3 високим рівнем інформованості, умотивованості до вмасного розвитку й постійної самоосвіти, здатності творчо мислити, громадянської активності й відповідальності, мобільності, гнучкості, здатності ефективно реалізовувати державну освітню політику та забезпечувати якість освіти.

Професійний розвиток педагога як очікуваний результат функціонування системи післядипломної педагогічної освіти змінює вектор цілепокмадання від наповнення знаннями до осмисленого особистісного зростання. Крім того, поступальний розвиток педагога як особистості і як професіонала здійснюється мише в ході практики, коми він займає позицію активного суб'єкта педагогічної діяльності, в якій реалізуються його творчий потенціал та здібності. Тож важмивим є формування випереджального характеру змісту післядипломної освіти та запровадження ефективних освітніх технологій організації практикоорієнтованого освітнього процесу.

Сьогодні в теорії та практиці післядипломної освіти спостерігається процес трансферу педагогічних технологій, метою якого є розширення ресурсної бази технологічного забезпечення освітнього процесу, спрямоване на створення освітніх практик, що підвищують якість педагогічної діяльності й забезпечують відкритість указаної системи, безперервність освіти, гнучкість освітнього процесу. Збільшення потенціалу освітніх технологій саморозвитку педагога відбу- 
вається за рахунок участі в їхній реалізації та вдосконаленні широкого кола суб'єктів освітнього процесу.

Проте трансфер педагогічних техномогій в систему післядипломної педагогічної освіти повинен передбачати виняткову неординарність навчання дорос-

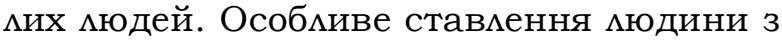
базовою освітою й професійним досвідом до навчання обумовлюють андрагогічні принципи організації освітньої діяльності, що відрізняються від педагогічних. Зокрема, педагогічні принципи, що реалізуються в процесі первинної професійної освіти, базуються на сприйнятті соціального досвіду: рольова позиція тих, хто навчається, в основному є пасивною, що детерміновано несформованістю професійно орієнтованих знань, умінь i навичок. Тоді як "доросла июдина сприймає себе самостійною, є самокерованою особистістю; має достатній запас життєвого, професійного досвіду, що допомагає здійснювати самоаналіз i цілепокладання освітньої діяльності; готова до навчальної діяльності, за допомогою якої можна розв'язувати професійні проблеми, досягти конкретних цікей; намагається застосовувати у своїй практиці набуті знання і навички" [6, с. 13].

Виходячи 3 того, що освітні техномогії є певною системою технологічних дій, їх можна об'єднати в декілька груп постійних і загальних цілей, які значною мірою визначатимуть форми навчання. Відомий американський ученийандрагог М. Ноулз виділяє шість таких "надцілей":

1) отримання знань (узагальнений досвід, інтеріоризація, оволодіння інформацією);

2) досягнення розуміння, усвідоммення (узагальнення й використання інформації на практиці);

3) отримання умінь (можливості нових практичних дій);

4) формування якостей (виникнення нових емоційних рис);

5) формування цінностей (сприйняття й паритетне ранжування переконань);

6) задоволення інтересів (прагнення до нових видів діяльності) [7].

Досягнення вказаних цімей можливе при використанні широкого спектру освітніх технологій, які забезпечують ефективність освітньої діяльності й особистісний розвиток педагогів.

Інноваційні освітні технології грунтуються на різних формах i рівнях співпраці, яка розвивається від максимальної допомоги викцадача (методиста) слухачеві-учителеві до послідовного зростання активності останнього й переходом до саморегульованих дій, налагодження конструктивного партнерства суб'єктів освітнього процесу [8].

Зіставлення якісних характеристик існуючих тенденцій розвитку інноваційних технологій навчання в системі освіти дорослих дозволимо виділити ефективні освітні технології організації практикоорієнтованої навчальної діяльності педагогів-слухачів, що мають значний стимуАюючий і розвивальний потенціал.

За типами взаємодії між суб'єктами освітнього процесу і освітнім середовищем можна виділити такі групи освітніх технологій: технології організації групової взаємодії, технології кооперативного навчання, технології організації самостійної роботи слухачів.

Технологія організації групової діяльності в закладах післядипцомної освіти грунтується на взаємодії слухачів з метою досягнення професійно значущого результату.

Ефективність ऑii реалізації визначають певні чинники, а саме: організація колективної пізнавальної діяльності педагогів, забезпечення позитивного емоційного мікроклімату, чіткий розподіл функцій, здійснення взаємодії, що вимагає індивідуальної відповідальності кожного, рефмексія групової роботи, що передбачає як аналіз результатів колективної роботи, так і самоаналіз.

Одним із варіантів організації групової діяльності $\epsilon$ технологія кооперативного навчання, що передбачає роботу в малих групах.

Необхідно зазначити, що форма взаємодії слухачів у групах може бути різною: спільно-індивідуальна, спільнопослідовна і спільно-взаємодіюча. Спільно-індивідуальна форма передбачає представцення підсумків власної діяльності кожного учасника, які обговорюються, і обирається доцільний варіант (найбільш характерне для технології організації групової взаємодії). При спіцьно-послідовній - результат діяльності кожного учасника $є$ фрагментом, необхідним дмя побудови загальної відповіді (найбільш характерне для технології кооперативного навчання). Спільновзаємодіюча форма обумовлює вибір певних аспектів рішення завдання, на основі яких ухвалюється групове рішення. 
Технології організації самостійної роботи слухачів дозволяють стимулювати активність, самостійність, пізнавальний інтерес і є імпульсом до подальшого саморозвитку. Специфіка післядипломної педагогічної освіти дозволяє розмежувати завдання для самостійної роботи на такі групи:

- для оволодіння знаннями - робота 3 різними джерелами інформації, навчально-дослідницька робота;

- для закріплення й систематизації знань - аналітична обробка тексту, підготовка відповідей на контрольні питання і тести, підготовка повідоммень до виступу на семінарах, засіданнях "кругмого столу", конференціях, підготовка рефератів;

- для формування вмінь - виконання варіативних завдань і вправ, розв'язання ситуаційних професійних завдань, підготовка проектів з введення інновацій в освітній процес, виконання випускної роботи [9].

У низці освітніх технологій, що сприяють конструктивному оволодінню кАючовими видами професійної педагогічної діяльності, можна виокремити технології контекстного навчання, технології науково-дослідної діяльності, проектні технології.

Технологія контекстного навчання, що реалізується за допомогою як традиційних, так і інноваційних форм і методів навчання, передбачає моделювання не $и$ пе предметного, але й соціального змісту професійної діяльності педагога. Переміщення слухачів у площину суб'єктів реальних педагогічних ситуацій, ділових і рольових ігор (грикомунікації, гри-захисту від маніпуляції, гри для розвитку інтуїції, гри-рефмексії й ін.), яким характерні неоднозначність i суперечність можливих рішень, а також їхній подальший аналіз сприяє професійному розвитку учителя.

Технологія контекстного навчання складається з трьох базових форм діяльності: навчальна діяльність з провідною ролмю мекцій і семінарів; квазіпрофесійна як така, що втілюється в іграх, спецкурсах, спецсемінарах; навчальнопрофесійна (практика на базі закладів освіти) [10].

Проектна і дослідницька діяльності забезпечують свідоме залучення педагога до розв'язання актуальної освітньої й соціокультурної проблематики; оволодін- ня ним сучасним знанням та іншими інтелектуальними засобами; адекватний сучасній освітній ситуації професійний розвиток педагога; створення якісного продукту професійної діяльності (якість освіти учнів); розвиток внутрішнього потенціалу педагога.

Використання проектної технології в закладах післядипломної освіти як особмивого виду інтелектуальної діяльності надає можливість проектування об'єкту (рівня розвитку), перспективного планування, практичної спрямованості, дослідницької роботи. Найбільш ефективними $є$ такі форми проектних технологій: опис вмасного педагогічного досвіду; авторська програма факультативу, спецкурсу або гуртка; методичні рекомендації викладання предмета (теми); методичні розробки уроків.

Основними ідеями дослідницького методу навчання $\epsilon$ використання наукового підходу до розв'язання педагогічних завдань, тобто побудова роботи слухачів відповідно до проведення класичного наукового пошуку з використанням усіх методів і прийомів наукового дослідження.

Професійно-особистісному розвитку педагогів сприяє також використання технологій розвитку системного i peфмексивного, у тому числі критичного мислення, евристичного та продуктивного навчання, ігрового моделювання.

Технологія розвитку критичного мисмення передбачає взаємодію та рефмексію суб'єктів освітнього процесу на усіх етапах навчання: спільна постановка цілей, спільна навчальна діяльність, визначення ступеню досягнення запланованих результатів (рефмексія).

Застосування цієї технології в освітньому процесі закладів післядипломної педагогічної освіти дозволяє організувати цілеспрямовану, змістовну діяльність, у ході якої інтелектуальна робота слухачів спрямована на розв'язання нагальних професійних проблем.

Під час пошуку й аналізу теоретичного матеріалу, зіставцення досвіду вцасної педагогічної роботи та альтернативної точки зору колег, використовуючи можливості колективного обговорення, учителі знаходять відповіді на актуальні питання навчання й виховання учнів.

Технології евристичного навчання учителів спрямовані на розвиток продуктивних процесів мислення та створюють умови для оволодіння новими, 
раціональнішими варіантами дій у нестандартних педагогічних ситуаціях.

Достатньо поширеним методом евристичного навчання є метод "мозкового штурму", що сприяє активізації колективної творчої діяльності. Відмінною особливістю його використання $є$ проблемність пошукового завдання й можАивість вибору різних варіацій ії рішення, навіть тих, які гіпотетично не можуть бути результативними. Далі організовується всебічне обговорення кожної ідеї й робиться висновок про доцільність застосування обраного варіанту. Це дає можливість педагогам побачити безліч різних поглядів на вирішення одного професійного завдання.

Технологія продуктивного навчання передбачає організацію певної діяльності слухачів, що формує уміння екстеріоризувати професійні знання.

Одним 3 методів, що повною мірою реалізовує ідеї продуктивного навчання, $\epsilon$ кейс-метод. Його використання в навчальному процесі закладів післядипломної освіти дає можливість розвивати в слухачів аналітичні, дослідницькі, комунікативні навички, формувати вміння аналізувати ситуацію, планувати стратегію, приймати рішення.

3 методичної точки зору, кейс - це спеціально підготовлений навчальний матеріал, який містить структурований опис ситуацій з реальної практики педагогів. Кейс єдиний інформаційний комплекс, у якому висвітлюється певна ситуація в різних аспектах.

У педагогічній практиці склалися такі види кейсів за способом надбання початкової інформації: "польові" (що грунтуються на фактах з реального життя) й "описові" (що базуються на вигадці автора); за визначеними цілями розрізняють ілюстративні й навчальні кейси.

Переваги кейс-методу порівняно 3 традиційними формами організації навчальної роботи зі слухачами полягають у тому, що, з одного боку, кейс-метод потребує чіткої структуризації інформації, а 3 іншого - створює важливу частину єдиної інформаційної бази, яка надалі може використовуватися педагогами [11].

Використання технологій ігрового моделювання дозволяє максимально набАизити освітній процес не мише до реальних умов взаємодії суб'єкта й об'єкта діяльності, але й до умов практичної взаємодії між педагогами.
Цілісне подання проблеми, що формується під час дікової гри, стає базовим дмя загальної дискусії й розуміння ії багатогранності. Відбувається розширення і поглиблення не мише фактичного знання, а й уміння погоджувати дії при розв'язанні педагогічних ситуацій.

Висновки i перспективи подапьших досліджень. Проблема розвитку професіоналізму вчителя сьогодні розробцяється науковцями, менеджерами освіти, освітянами-практиками. Попри певну відмінність поглядів щодо розуміння змісту поняття "професіоналізм педагога", його структури, розробценні різних підходів до розвитку професіоналізму вчителя, спільною $є$ думка що професіоналізм педагога $є$ інтегративним соціокультурним i психологопедагогічним утворенням, що зароджується на рівні внутрішніх умов (особистісного потенціалу мюдини) й набуває ознак професіоналізму в процесі спеціального зовнішнього впливу (педагогічної діяльності).

Вивчення змісту та особливостей реалізації освітніх технологій в системі післядипломної освіти свідчить про багатовекторність їхніх напрямів у контексті особистісного й професійного розвитку педагога.

Використання інноваційних техномогій у системі післядипломної освіти сприяє визначенню й чіткому усвідомценню вцасних переконань кожного учителя, що забезпечує підвищення рівня ефективності його подальшої професійної діяльності, усвідомлення ступеню взаємного впливу учасників освітнього процесу, творче використання досвіду своїх колег, нівелювання стереотипів педагогічної діяльності та формування мотивації педагога до подальшого професійного розвитку.

Здійснений аналіз не вичерпує всіх аспектів досліджуваної проблеми й засвідчує необхідність розробки системи моніторингу рівня розвитку професіоналізму педагогів, досліджень науковотеоретичних основ післядипломної педагогічної освіти.

\section{Список бібліографічних посицань}

1. Кузьмина Н. В. Профессионализм деятельности преподавателя и мастера производственного обучения профтехучилища. СПб.: Высшая шкома, 1989. 167 с.

2. Сластенин В. А. Профессионализм учителя как явцение педагогической культуры. Педагогическое образование и наука. 2008. № 12. С. 4-15. 
3. Багаева И. Д. Профессионализм педагогической деятельности и основы его формирования у будущего учителя : автореф. дис. … д-ра пед. наук : 13.00.04. Усть-Каменогорск, 1991. 36 с.

4. Гузій Н. В. Категорія професіоналізму в теорії i практиці підготовки майбутнього педагога : дис. ... д-ра пед. наук : 13.00.04. Київ, 2007. 475 с.

5. Дружилов С.А. Профессиональная компетентность и профессионализм педагога: психологический подход. Сибирь. Философия. Образование. 2005. №8. С. 26 - 44

6. Городова Н., Кучерявий О. Андрагогіка, або ЕАіксир професіоналізму... : модель особистісноорієнтованої підготовки педагогічних кадрів до творчої діяльності. Управління освітою. 2002. № 17. C. 12-15.

7. Набока $\Lambda$. Я. Особливості навчання дорослих 3 погляду педагогічної технології. Післядипломна освіта в Україні. 2007. № 1. С. 49-51.

8. Якухно I. І. Наукові основи інноваційного розвитку післядипмомної педагогічної освіти : монографія. Житомир: Полісся, 2010. 524 с.

9. Мезенцева О. И. Специфика организации самостоятельной работы педагогов в системе последипломного образования. Начальная школа. 2012. № 10. C. 1-5. URL: http://www.school2100.ru /upload/iblock/a73/a73ccf9cb4402bd18f2095e8e 3538eec.pdf.

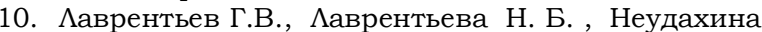
Н. А. Инновационные обучающие технологии в профессиональной подготовке специалистов. Ч. 2. Барнаул: Изд-во А^тайского государственного университета, 2002.146 c. URL: http://www2.asu.ru/cppkp/index.files/ucheb.files /innov/Part2/index.html.

11. Присяжнюк Ю. С. Використання інноваційних технологій у післядипломній педагогічній освіті. Післядипломна освіта в Україні. 2010. № 2. C. 24-27. URL: http://virtkafedra.ucoz.ua/ el_gurnal/pages/vyp6/prisjagnuk.pdf.

\section{References}

1. Kuzmina, N.V. (1989). Professional skills of teacher's and master's activity of vocational training in Vocational. St. petersburg: High School. 167 p.
2. Slastenin, V.A. (2008). Teacher's professional skills as a phenomenon of teacher's culture. Pedagogical education and science. 12. 4-15.

3. Bagaeva, I.D. (1991). Professional pedagogical activity of the future teacher and the basis of its formation (Doctor Sciences in Pedagogy Dissertation). Thesis. Ust-Kamenogsk. $36 \mathrm{p}$.

4. Guziy, N.V. (2007). A category of professional skills in the theory and practice of future teacher's training (Doctor Sciences in Pedagogy Dissertation). Kyiv: National Pedagogical University of M. P. Dragomanov's name. $475 \mathrm{p}$.

5. Druzhylov, S.A. (2005). Professional competence and a teacher's professional skills: psychological approach. Siberia. Philosophy. Education. 8. 26-44.

6. Gorodova, N., Kuchervyy, O. (2002). Andragogika, or an Elixir of professional skills...: A model of personal-oriented preparation of pedagogical staff to the creative activity. Educational management. 17. $12-15$.

7. Naboka, L.Ya. (2007). Peculiarities of Adult learning from the perspective of pedagogical technology. Postgraduate Education in Ukraine. 1. 49-51.

8. Yakkhno, I.I. (2010). Scientific fundamentals of innovative development of postgraduate pedag?gical education: Monograph. Zytomyr: Polissya. $524 \mathrm{p}$.

9. Mezentseva, O.I. (2012). Particularities of independent work of teachers in the system of postgraduate education. Primary school. 10. 1-5. Retrieved from http://www.school2100.ru/upload /iblock/a73/a73ccf9cb4402bd18f2095e8e3538eec. pdf.

10. Lavrentiev, G.V., Lavrentieva, N.B., Neudakhina, N.A. (2002). Innovational technologies in the professional preparation of specialists. Part 2 . Barnaul: Publishing house of Altai State University. 146 p. Retrieved from http://www2.asu.ru/ cppkp/index.files/ucheb.files/innov/Part2/index.h tml.

11. Prysyazhnyuk, Y.S. (2010). The use of innovative technologies in post-graduate pedagogical education. Postgraduate education in Ukraine. 2. 24-27. Retrieved from http://virtkafedra.ucoz.ua /el_gurnal/pages/vyp6/prisjagnuk.pdf.

\section{ZHOROVA Iryna}

Doctor in Pedagogy, Associate Professor, First Vice Rector,

Professor of Pedagogy and Management of Education Department, Communal Higher Educational Establishment "Kherson Academy of Continuing Education" of Kherson Regional Council

\section{MODERN TECHNOLOGIES OF DEVELOPMENT OF PEDAGOGISTS' PROFESSIONALISM IN THE SYSTEM OF POSTGRADUATE EDUCATION OF UKRAINE}

Abstract. Introduction. Teachers' training to the realization of the tasks of the New Ukrainian School, formation of their readiness to implement the academic freedom, motivation to self-education and selfimprovement actualize the search of modern methods, technologies of the development of pedagogists' professionalism in the system of postgraduate education.

Purpose. To reveal the meaning of the concept of " $a$ pedagogist's professionalism" and to consider modern technologies of pedagogists' professional development in the national system of postgraduate education.

Results. The analysis of scientific studies shows that teachers' professionalism is an integrative quality of a personality characterized by moral-and-spiritual qualities, acmeological position, pedagogical technique, professional competence, which are exteriorized in creative pedagogical activities and ensure the formation of key and intersubject competences in students. The development of pedagogists' professionalism takes place in the system of continuous education.

Today, in the theory and practice of postgraduate education, the process of transfer of pedagogical technologies is observed, the purpose of which is to expand the resource base of the technological support of the educational process, directed at the creation of educational practices that enhance the quality of scientific-andeducational activities and ensure the openness of the mentioned system, the continuity of education, the flexibility of the educational process.

Originality. Comparison of qualitative characteristics of existing trends of the development of innovative learning technologies in adult education system has allowed to allocate effective educational technologies of organization of the practice-oriented educational activity of pedagogists-students with significant stimulating and developing potential.

In a number of educational technologies that contribute to the constructive mastery of key types of professional pedagogical activities, one can distinguish: technologies of context learning, technologies of teaching scientific-and-research activities, project technologies.

The use of technologies of development of systemic and reflexive, including critical thinking, heuristic and productive learning, game simulation promotes pedagogists' professional and personal development. 
Conclusions. The use of innovative technologies in the system of postgraduate education contributes to definition and clear understanding of own beliefs of each teacher, which ensures improvement of efficiency level of its further professional activity, realization of the degree of influence of participants of educational process, creative use of experience of his colleagues, setting the stereotypes of pedagogical activity and forming motivation of teacher to further professional development.

The use of innovative technologies in the postgraduate education system helps to identify and to clear understand each teacher's individual beliefs, which ensures an increase of the level of effectiveness of his/her further professional activities, awareness of the degree of mutual influence of participants of the educational process, the creative use of the experience of his/her colleagues, the leveling of stereotypes of pedagogical activities and formation of a pedagogist's motivation for further professional development.

Keywords: a pedagogist's professionalism; educational technologies; postgraduate education.

Одержано редакиією 17.01.2019 Прийнято до публікаиії 21.01.2019

DOI 10.31651/2524-2660-2019-1-103-108

ORCID 0000-0002-2428-9262

КОРОБченКо Ангеліна Анатоліївна,

професор кафедри педагогіки і педагогічної майстерності, Мелітопольський державний педагогічний університет імені Богдана Хмельницького e-mail: angelinakorobchenko@gmail.com

ORCID 0000-0002-8767-1581

\section{ГОАОВКОВА Марина Михайцівна,}

доцент кафедри педагогіки і педагогічної майстерності,

Мелітопольський державний педагогічний університет імені Богдана Хмельницького

УДК 378.091.322:001.891 e-mail:m.golovkova.61@gmail.com

\section{НАУКОВО-ДОСАІДНИЦЬКА ДІЯАЬНІСТЬ ЯК ЗАСІБ ФОРМУВАННЯ ПРОФЕСІОНААІЗМУ МАЙБУТНЬОГО ВИКААДАЧА}

На підставі аналізу науково-педагогічних джерел доведено, шо науково-досліднииька діяльність майбутніх викладачів є невід'ємним елементом в системі вищої освіти, важливою складовою освітнього проиесу та засобом формування їхнього професіоналізму. В статті висвітлюються особливості організаиї та управління науково-дослідницькою діяльністю здобувачів вищої освіти. Визначено фактори, які позитивно й негативно впливають на розвиток науково-досліднииької діяльності. Також виокремлено перспективні напрями розвитку науково-дослідницької діяльності студентів. Доведено, шо управління науково-досліднииькою діяльністю студентів є складним, динамічним проиесом, який зорієнтований на розвиток особистості, розкриття творчого потениіалу.

Ключові слова: науково-досліднииька діяльність; професіоналізм; майбутній викладач; заклад вишої освіти; управління науководосліднииькою діяльністю.

Постановка проблеми. Науководослідницька діяльність є одним 3 найважливіших видів діяльності професорсько-викладацького складу та здобувачів вищої освіти. Проведення наукової роботи у закладі вищої освіти забезпечує безперервне вдосконалення освітнього процесу на основі фундаментальних і прикмадних досліджень з напрямів підготовки фахівців і впровадження в освітню діямьність сучасних методик і педагогічних технологій. Оновцення освіти на всіх ступенях тісно пов'язане з появою у сус- пільстві нової філософії, що затверджує пріоритет ві^ьної, самостійної особистості фахівця, здатного до самоосвіти і самовдосконалення. Сучасна практика вищої школи, на наш погляд, недостатньо зорієнтована на ефективне використання умов, які сприяють розвитку інтересу до науки у майбутніх викладачів. Проблема активізації науководослідницької діяльності полягає не у відсутності бажання здобувачів вищої освіти і викладачів займатися науковою творчістю, а у відсутності, з одного боку, системи управління науково-дослідною роботою, а $з$ іншої - у відсутності чітко окреслених педагогічних умов розвитку науково-дослідницької діяльності у закладах вищої освіти.

Аналіз наукових джерел засвідчує, що до проблем організації науководослідницької діяльності у закладах вищої освіти звертались А. Алексюк, Н. Гордій [1], І. Зязюн [2], А. Конверський [3], О. Крушельницька [4], О. Мартиненко, О. Микитюк [5], О. Пєхота [6], I. П'ятницька-Позднякова [7], 3. Слєпкань [8] та інші науковці. Проблемі теоретичних основ управління у закладах освіти присвятили свої праці Г. ЄАьникова [9], В. Маслов, В. Пікельна [10] та інші. 